\title{
EXPLORING THE LINKS BETWEEN OUT-MIGRATION AND SOCIAL DEVELOPMENT IN ROMANIA. A DEVELOPMENT REGION-BASED APPROACH
}

\author{
Bianca Mitrică $^{1}$, Nicoleta Damian² ${ }^{\text {iD }}$, Irena Mocanu ${ }^{1}$, Ines Grigorescu² iD \\ ${ }^{1}$ Human Geography and Regional Development Department, \\ Institute of Geography, Romanian Academy \\ 12 Dimitrie Racoviţă Str., sector 2, RO-023993 Bucharest: Romania \\ biancadumitrescu78@yahoo.com•mocanitai@yahoo.com \\ ${ }^{2}$ Environmental Geography and GIS Department, \\ Institute of Geography, Romanian Academy \\ 12 Dimitrie Racoviţă Str., sector 2, RO-023993 Bucharest: Romania \\ nicoleta_damian2002@yahoo.com• inesgrigorescu@yahoo.com
}

\begin{abstract}
In-migration into the EU has become an important issue in recent decades, as an important component accounting for population changes in Europe. In contrast, it was after the fall of communism that out-migration grew into a major - but also relatively new - phenomenon affecting Romania. Especially after 2002, in which year Schengen visa requirements were waived, rapid growth in circular migration was encouraged; with a further migratory wave ensuing after 2007, due to free access to the European labour market. Against that background, work detailed in this paper has sought to provide insights into specific features of the process of out-migration, as this relates to social development. Use was made of statistical data available at NUTS 2 (Development Regions) level, as provided by the National Institute of Statistics; as well as various further data and information from both the World Bank and EUROSTAT. To achieve the objective specified above, efforts have been made to select indicators shown to offer a broad and accurate picture of both out-migration (via an out-migration rate indicator) and levels of social developmental (via a Socially Disadvantaged Index). The effects of what mainly proves to be temporary out-migration are very important, as they drive temporary loss of human capital, with Romania appearing in statistics among the main sources of labour-migration flows.
\end{abstract}

Keywords: Development Regions, disparities, out-migration, Romania, social development.

\section{Introduction}

Due to its large-scale effects, migration is one of the socio-economic phenomena of global attention studied during periods of both crisis and economic boom (EP, 2018), which has become more complex (Horváth \& Anghel, 2009, EUSDR, 2015), and is more likely to remain so in the future (Vimont, 2016). Migration involves two phases: (1) the emergence of a group with major potential to migrate, and (2) the actual move made by this group (Docquier, Peri \& Ruyssen, 2014, as cited in: lanoș, 2016). The various causal factors may be favourable, unfavourable or neutral. From the perspective of economists, migration is a flow from regions of lower to higher labour productivity that leads to economic gains, despite the uneven distribution. Moreover, beyond the economic dimension, there is a cultural and social impact to migration (EIB, 2016). 
In recent years, Europe has faced its most severe migratory challenge since the 1990s, with issues of migration coming to be of major interest, and with both permanent and temporary labour migration gathering pace. At the European level, the demand for unskilled labour has increased, especially in agriculture, construction and domestic services - in the cases of countries like Italy, Spain, Greece, Portugal and Germany. Migration has increased mainly in Germany and the United Kingdom - due to policies pursued to recruit foreign labour force for certain periods, as well as the numbers of foreign students present in these host countries (Tudorache, 2006).

During 2017, 4.4 million people immigrated into one or other of the European Union (EU) member states, while at least 3.1 million emigrants left an EU member state. Germany reported the largest total number of immigrants in 2017 (917,100), followed by the United Kingdom $(644,200)$, Spain $(532,000)$, France $(370,000)$ and Italy $(343,400)$. Germany also reported the highest number of emigrants in $2017(560,700)$, followed by Spain $(368,900)$, the United Kingdom $(359,700)$, France $(312,600)$, Romania $(242,200)$ and Poland $(218,500)$. A total of 22 of the EU member states reported more immigration than emigration in 2017 (EUROSTAT, 2019b).

After the fall of the totalitarian regimes, Central and Eastern Europe countries (CEEC) became an important source of migrants, especially for the older countries of the EU (Sandu, Radu, Constantinescu \& Ciobanu, 2004, lanoș, 2016). While the population of most of the CEECs (the Czech Republic, Slovakia, Hungary, Poland and Romania) migrates to Western European countries, the same countries serve as a destination for migrants from Eastern European countries (like Belarus and Ukraine). However, during 2017, Bulgaria, Croatia, Latvia, Lithuania, Poland and Romania all experienced situations in which numbers of emigrants exceeded those of immigrants (EUROSTAT, 2019b).

Migration flows among European/EU countries and inside and outside Europe/the EU have exerted a significantly influence on the current population sizes of most countries (EUROSTAT, 2019b). Had there been no positive net migration, the 2000-2015 period would have witnessed a decline in population in Europe. Even then, current migration trends (in a medium-variant scenario) will not be enough to compensate for natural balance between 2020 and 2025, ensuring that the decline in Europe's population becomes even more pronounced, and starts earlier, i.e. by 2015-2020 (under a zero-net-migration scenario) (UN, 2017).

In Romania, territorial mobility has manifested itself as a broad demographic process, through social and economic implications which have been tangible in areas of both departure and arrival (Ghețău, Damian \& Simion, 2016). In the case of Romania's out-migration, both the push and pull factors are primarily of a socio-economic nature. Thus, the favourable economic conditions at the destination (the prospect of higher wages and better opportunities for employment and wealth creation) can combine with a desire to escape the domestic social and political environment to attract people into migrating. On the other hand, if economic conditions are unfavourable at the place of origin - being characterised by poverty, inequality, lack of infrastructure and unemployment, individuals are then 'forced' to migrate in order to sustain or improve their livelihoods (WEF, 2017).

While the situation in Romania pre-1990 was characterised by internal migration, the fall of the communist regime gave rise to out-migration. This reached its maxim flux, given that net out-migration is partially responsible for the demographic decline also reflecting a decrease in birth rate, increased mortality and a change in family demographic practices (Suditu, Prelipcean, Vîrdol \& Stângaciu, 2013). In 2017, it was Romania that registered the greatest number of its citizens living in other EU and European Free Trade Association (EFTA) countries (at 3 million); as followed by Poland, Italy, Portugal and the United Kingdom (IOM, 2017). Romania's migratory processes are and remain part of a wider process of regional development taking place in European countries with relatively weak economies (Heller, 2013). 
According to Roman and Voicu, 2010, the out-migration phenomenon in Romania has had several stages:

1) 1990-1993, with massive emigration of (mainly German and Hungarian) ethnic minorities to Western Europe. According to Eurostat, 96,929 people left Romania in the period immediately following the fall of the communist regime - due to the opening of the borders - with 170,000 people reached in the next three years (Tomescu-Dumitrescu, 2017).

2) 1994-1996, with migration to Western Europe only at a low level, with this especially relating to seasonal or illegal work. As a consequence of visa restrictions and work permits being introduced, the migration rate out of Romania decreased, while the temporary migration rate experienced an unprecedented explosion, transforming into a worrying phenomenon of profound social, economic and psychological implications (Tomescu-Dumitrescu, 2017).

3) 1996-2001, with the out-migration phenomenon becoming more complex and featuring several trends: i.e. increased permanent migration to the USA and Canada, rather than to European countries - from 1999 illegal or circular migration for work; an increase in migrant traffic overlapping with illegal migration characterised by abuses on the part of traffickers; a small number of Romanian migrants returning from the Moldova, as well as a strong influx of Romanian migrants between Germany and Romania.

4) 2002-2007, with the waiving of the Schengen visa promoting rapid growth in circular migration and a return of Romanians from the Schengen countries as a result of the visa requirement in this area being eliminated.

5) post 2007, with free access to the European labour market proving favourable to both the latter's creation and the recording of severe slippages on local markets (Anghel, Botezat, Cosciug, Manafi \& Roman, 2016, lanoş, 2016). While the main destinations for Romanians immediately post-accession were Italy and Spain, worsening economic and social conditions there gave rise to a substantial increase in emigration to the United Kingdom.

According to data provided by National Institute of Statistics (2019), it was in 2018 that the largest numbers of migrants at any time in the period of the last 10 years were registered $(238,926$ people). The last four years have seen more than 800,000 people leave the country (or $4.4 \%$ of Romania's resident population as of January 1, 2019). At presently, the departures for Western Europe are at least partly compensated by immigration from the Republic of Moldova, and increasingly also other countries (like Ukraine and Italy).

The work detailed here has sought to explore the links between out-migration (as indicated by the out-migration rate) and social development (as reflected in a so-called Social Disadvantage Index) in the case of Romania. A study with this aim was therefore carried out at the level of Romania's eight Development Regions (DRs) corresponding to NUTS 2 level (and known as the North-West, Centre, North-East, West and South-East, as well as South-Muntenia, Bucharest-Ilfov and South-West Oltenia).

\section{Data and methodology}

The study was run using statistical data available at the NUTS 2 (Development Region) level, as provided by Romania's National Institute of Statistics and the TEMPO-Online time series (NIS, 2019). In addition, in achieving a general overview of out-migration, we drew on various data, studies and reports from Eurostat, the European Commission, World Bank and International Organization for Migration. 
To highlight the anticipated links between out-migration and social development, the study took account of two specific indicators, i.e. out-migration rate (O-MR) and the Social Disadvantage Index (SDI), the time horizon being the year 2017. The O-MR is the number of people moving from one country to another with a change of place of residence permanently or for a long period (as related to 1000 people in the sending area, i.e. the Development Region of Romania, in this case).

$$
O-M R=\frac{E_{-} M G R}{P O P} * 1,000
$$

Where: E_MGR - number of emigrants leaving an area; POP - total population.

It is now acknowledged rather widely that resort to a large number of different indicators can encourage confusion, rather than focus (Sandhu-Rojon, 2015). Thus, from a methodological point of view, the worked carried out has sought those situational indicators capable of providing a broad and accurate picture of social developmental status in Romania, as revealed by the SDI. The computation of this composite index involves a rich database, with the statistical indicators chosen by reference to the relevant scientific literature (e.g. Fererra, 2005; Marlier \& Atkinson, 2010; Copeland \& Daly, 2012; Abreu, Nunes \& Mesias, 2019), European and Romanian reports, and scientifically-sound official documents focusing on territorial disparities and social-development issues (Anania \& Tenuta, 2006; MRDPA, 2014). However, as a composite indicator, SDI needed to meet several important requirements related to the selection of variables (e.g. relevance, availability, data continuity and homogeneity), and the provision of an exploratory analysis focused on the overall structure of the integrated indicators (Sandu, 2011; Victora, Black, Boerma \& Bryce, 2011; Michalek \& Zarnekow, 2012). Statistical indicators potentially emphasising the general level of social development and the typologies are nevertheless numerous (e.g. OECD, 2007, 2009; Dijkstra \& Poelman, 2008; Dijkstra \& Ruiz 2010; van Eupen et al., 2012; Bański \& Mazur, 2016), so a graph matrix was applied to establish the degree of determination or subordination of each (Tudor \& Rusu, 2011; Stângă \& Grozavu, 2012). This brought the authors to a 21-indicator selection able to highlight the main components to social development (demography, education, health, habitat, occupancy, transport and culture), as well as areas most favourable or unfavourable to social development (i.e. either advantaged or disadvantaged).

As variables relating to the above statistical indicators are calculated using different measurement units, a standardisation procedure was required - and took the form of a min-max normalisation technique (lanoş, 1981; Mitrică, Bogardi, Mitrică, Mocanu \& Minciună, 2017). The results were values for SDI computed as Hull scores ${ }^{4}$ :

\footnotetext{
INF_MORT + AGING +DEM_DEP + ROMA + AGRI_EMPLOY + UR - LIVING_FLOOR - GROSS_EAR - TEACH + ABAND -PHYSIC - BED_SANIT $S D I=50+14 *+$ FAM_ALLOW +SOC_ALLOW -DRINK-WAT_NET -NAT-GAS_NET -SEW_NET - TRANSP - PASS_TRANSP -VISIT_MUS - AUD_ENTER
}

Where: INF_MORT - infant mortality rate (\%o); AGING - ageing index; DEM_DEP - demographic dependency rate (\%); ROMA - roma population (\%); AGRI_EMPLOY - employment in agriculture (\%); UR - unemployment rate (\%); LIVING_FLOOR - floor space for living in (m2/inh.); GROSS_EAR - average monthly nominal gross earnings (lei/inh.); TEACH - classroom teachers (no./1000 pupils); ABAND - abandonment rate in primary and lower-secondary education (\%); PHYSIC - physicians (no./1,000 inhabitants); BED_SANIT - beds from sanitary unit (no./1000 inh.); FAM_ALLOW - family allowance targeted at families caring for children whose incomes are lower than the threshold set by law (lei/household); SOC_ALLOW - social allowances assuring the minimum guaranteed income (no. of beneficiaries/100 households); DRINK-WAT_NET - total length of the drinking water supply network ( $\mathrm{km} / \mathrm{inh}$.); NAT-GAS_NET - total length of the pipeline distribution

\footnotetext{
${ }^{4}$ The score Hull, named after its originator, is a way of transforming $\mathrm{Z}$ score into a simpler measure of relative position defined in points from 0 to 100 (Cohen \& Holliday, 2001).
} 
network for natural gas ( $\mathrm{km} / \mathrm{inh}$.$) ; SEW_NET - total length of sewerage ( \mathrm{km} / \mathrm{inh}$.); TRANSP - density of the transport network $(\mathrm{km} / 100 \mathrm{~km} 2)$; PASS_TRANSP - passengers transported by local public transport (no.); VISIT_MUS - visitors to museums (no.); AUD_ENTER - audience in entertainment institutions (no.).

Each statistical indicator was also chosen so as to emphasise other social issues of Development Regions. Thus, whole average monthly nominal gross earnings reveal the level of a population's incomes, these indicators also underline how deep-rooted are the socio-economic problems of the poor population lacking access to some of the conditions considered fundamental for life.

\section{The study area}

The study focuses on the Development Regions of Romania - at NUTS 2 level (Fig. 1). Designed as regional spaces with specific development problems, the Development Regions are delimited as functional spaces of comparable size composed of units with different levels of economic and social development. In terms of area and demographic size, Romania's Regions other than Bucharest-Ilfov differ only slightly, corresponding in this way with NUTS 2 of the EU's Territorial Units Nomenclature (Table 1). In socio-economic terms, differentiation is moderate, except in the case of the North-East Development Region with its less-favourable performance (RG/EC, 1997; Popescu \& Săgeată, 2016).

The starting point for the delimitation of Romania's Development Regions was the elaboration of a study on regional disparities, on the basis of the socio-economic evolution taking place in the 1990-1994 period. The development-gap analysis took account of indicators grouped into five categories of: the economy, infrastructure, household resources, socio-demography and urbanisation (Hansen, lanoş, Pascariu, Platon \& Sandu, 1996). The study highlighted the existence of well-defined regional disparities in the level of development overall, with the South and East being least-developed, while the West and Centre of the country had developed the most. The explana-

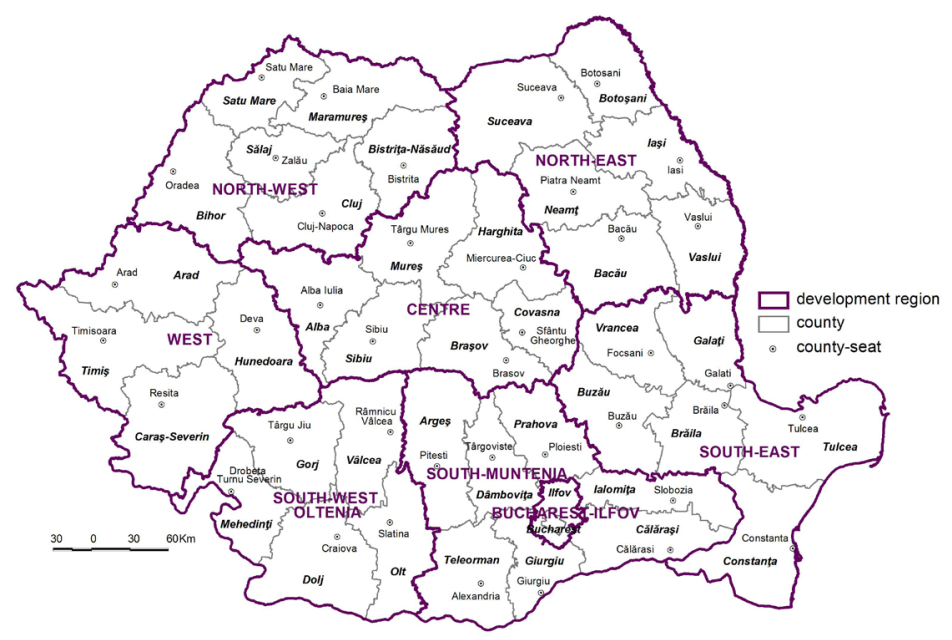

Figure 1. Romania's Development Regions 
Table 1. Main characteristics of the Development Regions (2017)

\begin{tabular}{|l|c|c|c|c|}
\hline \multicolumn{1}{|c|}{$\begin{array}{c}\text { Development } \\
\text { Region - NUTS 2 }\end{array}$} & Counties - NUTS 3/LAU 1 & Region centre & Population & Area (ha) \\
\hline North-West & $\begin{array}{c}\text { Bihor, Cluj, Bistriţa-Năsăud, } \\
\text { Maramureş, Satu Mare, Sălaj }\end{array}$ & Cluj-Napoca & $2,836,219$ & $3,416,046$ \\
\hline Centre & $\begin{array}{c}\text { Alba, Braşov, Covasna, } \\
\text { Harghita, Mureş, Sibiu }\end{array}$ & Alba-lulia & $2,634,748$ & $3,409,972$ \\
\hline North-East & $\begin{array}{c}\text { Bacău, Botoşani, laşi, Neamţ, } \\
\text { Suceava, Vaslui }\end{array}$ & Piatra-Neamţ & $3,939,938$ & $3,684,983$ \\
\hline South-East & $\begin{array}{c}\text { Brăila, Buzău, Constanţa, Galaţi, } \\
\text { Tulcea, Vrancea }\end{array}$ & Brăila & $2,859,897$ & $3,576,170$ \\
\hline South-Muntenia & $\begin{array}{c}\text { Argeş, Călăraşi, Dâmboviţa, } \\
\text { Giurgiu, lalomiţa, Prahova, } \\
\text { Telorman }\end{array}$ & Călăraşi & $3,242,876$ & $3,445,299$ \\
\hline Bucharest-IIfov & IIfov, Bucharest Municipality & Bucharest & $2,510,877$ & 182,115 \\
\hline South-West Oltenia & $\begin{array}{r}\text { Dolj, Gorj, Olt, Mehedinţi, } \\
\text { Vâlcea }\end{array}$ & Craiova & $2,194,235$ & $2,921,169$ \\
\hline West & $\begin{array}{r}\text { Arad, Caraş-Severin, } \\
\text { Hunedoara, Timiş }\end{array}$ & Timişoara & $2,012,053$ & $3,203,317$ \\
\hline
\end{tabular}

Source: NIS (2019).

tions for this state of affairs prove complex, with the East and South very rural in character and only experiencing industrialisation after 1970. To be added to that description is the absorption effect exerted on the south by Bucharest (Grimm, Friedlein \& Müller, 1997). Meanwhile, the Central and Western parts of the country are favoured by mature industries, have better-developed services and urbanisation of longer tradition (Popescu \& Săgeată, 2016).

According to Sandu (2011), at the level of the historical region, social development allows for the identification of minimum and equal values for three main regions of Moldova, Muntenia and Oltenia (as matching the North-East, South-Muntenia and South-West Oltenia DRs, respectively). The maxima in turn characterise Transylvania, Banat and Bucharest-Ilfov (as overlapping with the Centre, West and Bucharest-Ilfov Development Regions).

\section{Results and discussions}

\section{Disparities in the level of social development}

Romania is facing challenges, as is revealed by the 21 social indicators selected to highlight such main components of social development as demography, education, health, habitat, occupancy, transport and culture. These challenges relate to a number of the Social Scoreboard indicators supporting the European Pillar of Social Rights, given comparatively high early school-leaving and NEET rates (Not in Employment, Education or Training), and a relatively large gender-related employment gap. In addition, the country is at high risk of poverty and social exclusion, as well as income inequality. The inactivity of large segments of the working-age population is still an issue despite improvements in the labour-market performance. Roma and people with disabilities also have difficulties finding jobs, while per capita expenditure on social protection is among the EU's lowest (EC, 2018a). 
Against that background, it was felt that analysis of region-to-region differences in regard to these indicators would do much to reveal areas advantaged or disadvantaged where levels of social development are concerned.

Computed SDI values range from 45.428 in Bucharest-IIfov (identifying this as the most socially-developed DR) to 51.888 in the South-East Development Region, which is therefore least-developed socially.

The socially-advantaged DRs are thus Bucharest-Ilfov, West, North-West and Centre, whose indicators all assume values opposite to those noted in disadvantaged regions. That said, even these Development Regions include certain isolated pockets or grouped areas in which values for the SDI are high or even very high (meaning that they are highly disadvantaged in terms of their social development). At the level of the whole Development Regions, those identified as disadvantaged socially are the South-East, South-West Oltenia, South-Muntenia and the North-East. The main 'sources' of these lowest social-development levels are in turn down to certain highly-disadvantaged areas, such as the counties of Vaslui (in the North-East DR), Olt and Mehedinți (South-West Oltenia), and Teleorman and Călărași (in South-Muntenia) (Fig. 2).

Social disadvantage is found to be shaped by (high values for) such indicators as infant mortality, demographic dependency, population ageing, population employed in agriculture, unemployment, social and family allowances. Beginning with infant mortality rate (INF_MORT), and an ongoing downward trend post-2000 (to 7.07\% in 2017 from 18\%o then) does not obscure the fact that highest values continue to be registered in the DRs that are most disadvantaged socially (with infant mortality in the 6.8-7.8\% range in South-West Oltenia and the South-East Development Regions, among others). The fact that high values for demographic dependency rate (DEM_DEP) are linked with population ageing, low birth rates and out-migration (especially of the young working-age population) is what explains values over $50 \%$ registered for the South-East, South-West Oltenia, South-Muntenia and the North-East (in which the highest noted value was $55.11 \%$ ). Then, where the ageing index (AGING) is concerned, the North-East is the only Development Region

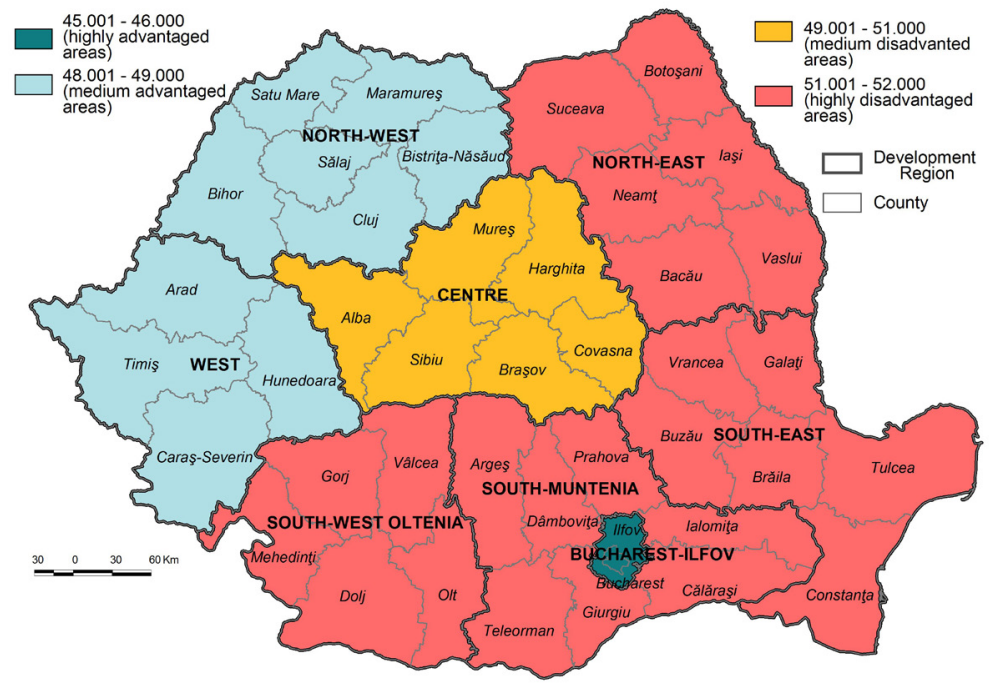

Figure 2. SDI spatial distribution of the Development Regions ${ }^{1}$

\footnotetext{
${ }^{1}$ Figures 2-9 elaborated based on NIS data.
} 


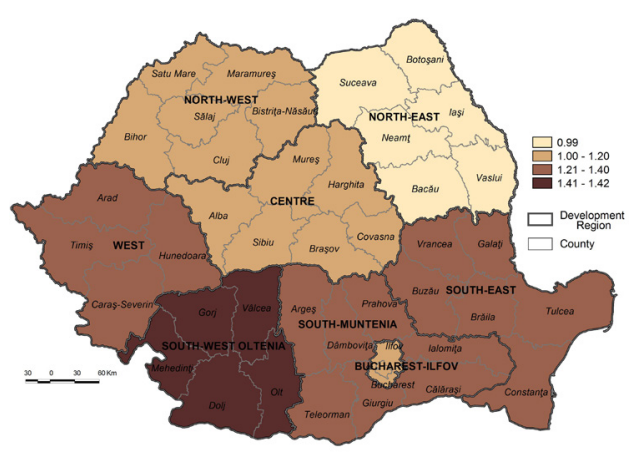

Figure 3. Aging index

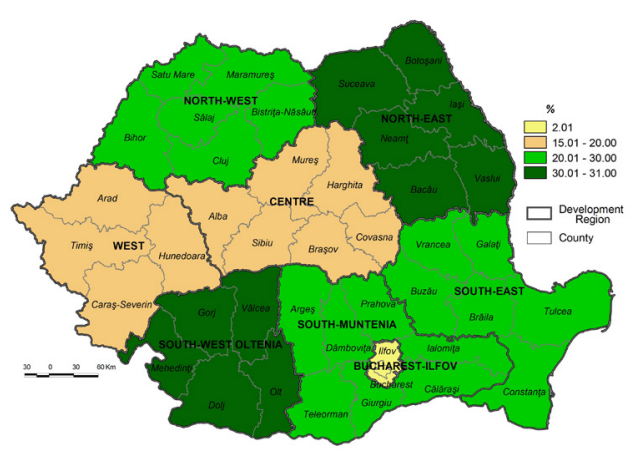

Figure 4. Rate of employment in agriculture

with sub-unit values, since eastern Romania is known for its values for births compared with other regions. The most aged population is thus in the South-Muntenia and South-West Oltenia Development Regions, where index values are 1.34 and 1.42 respectively (Fig. 3). The South-East, SouthWest Oltenia, South-Muntenia and the North-East - all mentioned as disadvantaged socially - register the highest values (over $25 \%$, i.e. a very high value by the standards of EU states - for which the average is $4.5 \%$ (EUROSTAT, 2019a) when it comes to the indicator of employed in agriculture (AGRI_EMPLOY). Most of the area with highest values coincides with the Romanian Plain and Moldavian Tableland, traditionally agricultural and with a large share of rural population (Fig. 4).

These Development Regions also 'lead' as regards unemployment rate (UR; with South-Muntenia noting 6.3\%, the North-East 6.5\%, the South-East 6.7\% and South-West Oltenia 8.3\%); and also when it comes to indicators relating to family and social allowances (FAM_ALLOW, SOC_ALLOW; e.g. family allowance was at a level of almost 108 lei/inh. in the North-East, a high value when set against a national average of 59.32 lei/inh). Similarly, social allowance, whose aim is to guarantee minimum financial support for single persons, or families on lower income, is most claimed in South-West Oltenia, where there are 3.21 beneficiaries per 100 households.

In four Development Regions located in the eastern, south-eastern, south and south-western parts of Romania, social disadvantage is reflected in lowest values for the indicators of: number of physicians and hospital beds, lengths of distribution pipes carrying natural gas and of the sewer network, and passengers transported by local public transport. The circumstances in which values for these indicators are lower than elsewhere connect with disadvantaged communities being prevented from escaping poverty, given restricted access to employment, education and social services (EC, 2018b), and also prevented from achieving a decent quality of life given precarious spatial and economic accessibility to health and cultural services, to the national and pan-European transport networks, etc. The North-East and South-East, South-West Oltenia and South-Muntenia Development Regions all present poor healthcare infrastructure (mirrored by number of physicians (PHYSIC), which is even lower than the national average -2.58 , itself below the European value of 3.40 physicians/1,000 inh. (OECD, 2017); as well as by the number of hospital beds (BED_SANIT) indicator, whose lowest reported value is that characterising the South-Muntenia Development Region - at 4.15 hospital beds/1,000 inh. (Fig. 5).

Despite annual increases in the indicator involving the total length of the sewerage network (SEW_NET), only four Development Regions (Bucharest-Ilfov, the North-West, West and Centre) report values over the national average - at between 1.95-2.14 km/inh.; while the other four Regions are below it, at between 1 and $1.48 \mathrm{~km} /$ inh., respectively in the North-East and South-East DRs. 


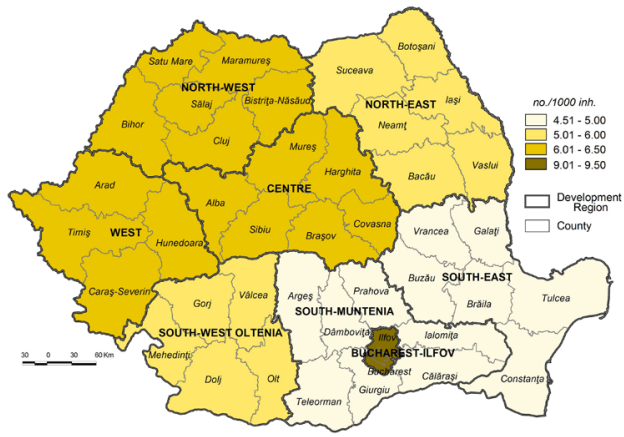

Figure 5. Number of hospital beds

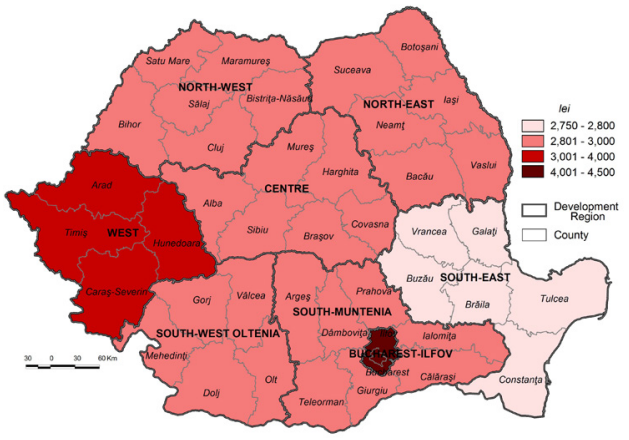

Figure 6. Average monthly nominal gross earnings

However, this measure has some limitations related to the insufficient territorial expansion of the water supply and sewerage networks, partial lack of water metering at the level of the consumer, high water loss due to lack of maintenance of the system, maintenance costs not covered by tariffs, and the lack of a system for collecting wastewater (Mitrică et al., 2017).

Any social advantages possessed by the Bucharest-Ilfov, West, North-West and Centre Development Regions are mainly correlated with high values for average monthly nominal gross earnings (GROSS_EAR). This indicator is linked with each region's economic development and the specificity of economic activity. Thus, outstanding in Romania (at over 4,300 lei/pers., where 1 euro -4.75 lei) is Bucharest-Ilfov, whose figures are nearly twice those to be noted in other less-developed regions, i.e. the South-East (2,750 lei/pers.), South-West Oltenia (2,812 lei/pers.) and the NorthEast (2,814 lei/pers.) (Fig. 6). In this last Development Region most counties have a prevalence of agricultural activities allowing people to earn perhaps 2,500 lei/pers. per month (Fig. 6).

\section{Out-migration}

According to the National Institute of Statistics, out-migration of a more permanent nature characterising the 1990-2017 period resulted in Romania losing 550,326 people from its population total. The preferred countries of destination for such permanent migration were Germany, Italy, Spain (over 40,000 people each), followed by the United States of America and Canada (over 26,000 each) and Austria, Hungary and France (10,000-14,000 each) (NIS, 2019). The out-migration push factors reflect shortcomings of the business environment (even as new companies are being created), and a lack of housing revealing that the low incomes the country can offer are insufficient to allow people to invest in real estate (Prada, Ciupureanu \& Otoiu, 2015).

At the Development Regions level, a more dynamic trend over the 1992-2017 period in terms of permanent out-migrations is registered by Bucharest-Ilfov (accounting for $21.3 \%$ of all migrants) followed by the Development Regions of the Centre (18.2\%) and West (16.6\%) - due to their high levels of social development (Fig. 7). The highly-skilled emigrants from Bucharest-Ilfov are mainly Romanians, while those leaving the Centre and West DRs tend to be from (German or Hungarian) ethnic minorities.

Overall, some $10 \%$ of the EU's highly-skilled population are living abroad, though this figure disguises huge differences between member states, with the Romanian figure - as of 2010 - being at almost 23\%, following an increase in the whole period from 1980 (Batsaikhan, Darvas \& Gonçalves Raposo, 2018). 


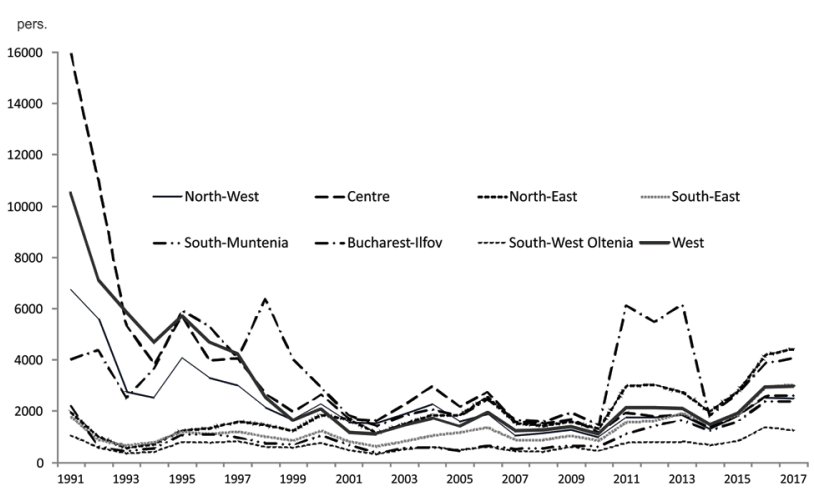

Figure 7. Dynamics of permanent emigrants by Romanian Development Region (1992-2017)

The last places in the hierarchy in this context are taken by the South-West (on $4.0 \%$ ) and South-Muntenia (6.0\%), as two of the poorest Development Regions, in which potential or actual migrants tend to be low-skilled. Intermediate numbers of permanent emigrants characterise the North-East (12.1\%) and North-West (13.7\%) (Fig. 7).

Analysis of the dynamics to temporary out-migration over the 2012-2017 period reveals an increase from 170,186 to 242,193 people, with the highest values registered by the North-East and South-Muntenia Development Regions (over 170,000 pers. each, representing $16.1 \%$ and $15.5 \%$ respectively). The lowest are in turn noted for the West and South-West Oltenia Development Regions (105,932 and 119,288 , or $9.2 \%$, respectively $10.4 \%$ ) (Fig. 8). Even the country-specific mobility figures show that, while Germany and the UK are the main destination countries for migrants from the EU'S CEECs in general, Romanians have shown a preference for moves to Italy and Spain. Almost three times as many Romanians have gone there as to Germany and the UK combined.

The structure of the data for emigrants shows that, at the whole-country level, $91.3 \%$ are of a temporary nature, while the remaining $8.7 \%$ are permanent. However, shares of all emigrants capable of being characterised as permanent range from $4.7 \%$ in South-West Oltenia and $5.9 \%$ in South-Muntenia through to $13.1 \%$ in Bucharest-Ilfov and $11.8 \%$ in the West Development Region. The main idea relating to this is that emigrants assigned permanent status largely leave from the Development Regions achieving a high level of social development, while their temporary counterparts leave Regions where the level of social development is low.

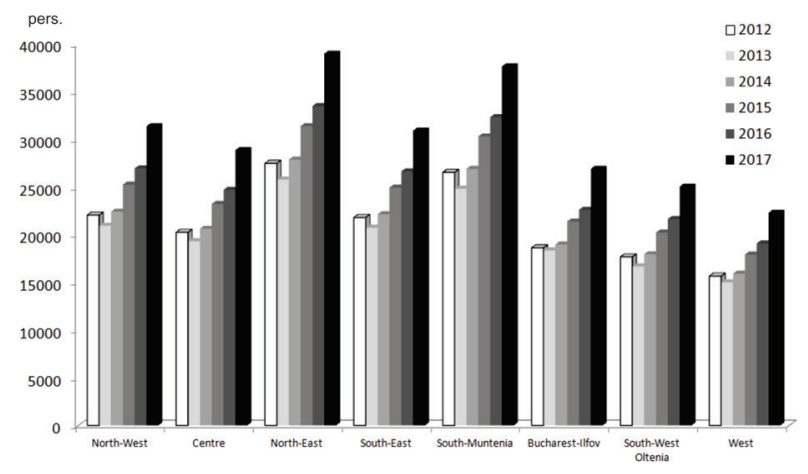

Figure 8. Dynamics of temporary emigrants by Romanian Development Regions (2012-2017) 
The real overview is reflected by the out-migration rate (O-MR), for which extreme values range from the $11.0 \%$ noted for the North-East Development Region to the $12.6 \%$ o characterising the Western Region. As set against a national average of $11.9 \%$, only one DR (the North-East) is seen to have a lower value, while two are on the same level of 11.9 (i.e. the South-East and NorthWest) (Fig. 9).

The highest values for out-migration rate (of between 12.1 and $12.6 \%$ ) mostly characterise regions that are highly developed socially (like the Western and Bucharest-Ilfov DRs). The one exception here is the South-Muntenia Development Region, where the level of social development is low.

National-average values for the out-migration rate are recorded in 4 DRs, among which two (the Centre and North-West) enjoy a high level of social development, while two have a medium-low level (that is South-West Oltenia and the South-East).

The lowest values for out-migration rate $(11.0 \%)$ are registered in the North-East Development Region, which is one of the country's poorest, and an out-migration 'pool' in both 2002 and 2007.

Emigrants generally belong to two main categories, being either highly-qualified people, or people with medium-level or low qualifications. In the first case, those involved will tend to be: (1) highly-qualified individuals from the fields of medicine or ITC (for example, with the more than 14,000 physicians working abroad in 2013 representing more than $26 \%$ of all physicians in Romania); or: (2) young people studying abroad, the numbers of which have more than doubled in the last 16 years - from about 12,500 in 2000 to about 33,400 in 2016. Europe is the main destination, followed by the United States. In contrast, the number of students in Romania declined from 900,000 in 2009 to 405,000 in 2016 (World Bank, 2018).

In the second case, emigrants usually perform jobs Westerners tend to avoid: in construction, and especially the less-qualified end of that work, in domestic activities (with many women taking care of elderly people or children), and in seasonal work (as so-called 'strawberries'). It is typical for these people to hail from remote and poor rural areas, where incomes are lower, along with the economic capacity to absorb labour force.

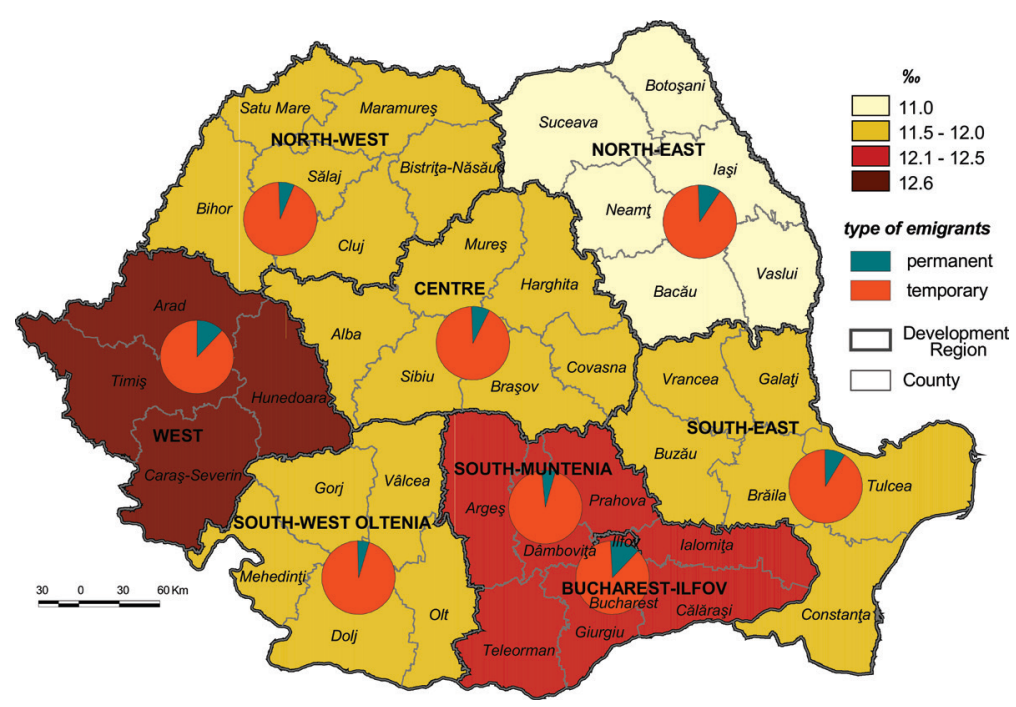

Figure 9. Out-migration rate by Development Regions of Romania in 2017 
Depending on gender, emigrants' behaviour can be markedly disparate. Thus, while in early 2000 , it was the share of male emigrants that was highest (HotNews, 2015, September 4), by 201213 the percentages where higher for females - the figures being $58.4 \%$ and $59.2 \%$, respectively. However, as of 2017, the share was close to equal, with the breakdown at $50.1 \%$ male to $49.9 \%$ female. Where consideration concerns Development Region of origin, it is noted that four (the South-West Oltenia, South-Muntenia, the North-West and the Centre) all registered a rather high proportion of males, while one (the West DR) was characterised by a relatively higher share of females. That left three Regions in which the shares were about equal. Where permanent emigrants are concerns, the prevalence in all Development Regions relates to the female population, with range being between $55.0 \%$ in the Bucharest-Ilfov Development Region and $56.8 \%$ in the Centre DR. A feminisation of out-migration flows can thus be noted, with the role played by women thus proving of increasing significance, in both quantitative terms and as regards the social roles of those participating in the process (King et al., 2006).

A feature of the emigrant population's structure by age is that the highest share characterises 15-65 year-olds, with all Development Regions registering the same percentage for these - of $87.6 \%$. The young age group accounts for $10.1 \%$, elderly people just $2.3 \%$. An increase in the dimensions of international migration, with population of working age mainly involved, will generate major problems on the labour market, in the pension system and, in general, in relation to medium- and long-term financing of social services. 53.4\% of all emigrants nationally are from urban areas, with values regionally varying from $39.3 \%$ in the South-Muntenia DR to $89.7 \%$ in the Bucharest-IIfov DR (Table 2).

Overall, the Development Regions with a high level of social development registered more high-skilled workforce emigrants from urban areas, while those with a low level of social development provide more of the low-qualification emigrants from rural areas.

In general, then, Romanian migrants are either highly-qualified workforce aged 25-40, and with competences in the top fields of science and technology and in areas such as education and health (thereby representing the so-called 'brain drain') (Beine, Docquier \& Rapoport, 2001; Bhargava, Docquier \& Moullan, 2011; Brădăţan \& Kulcsár, 2014; Botezat, Moraru \& Botezat, 2016); or they are unskilled or semi-skilled workers in agricultural activities, sanitation and construction. Preferred destination countries were Spain, Portugal and Greece. In between these two situations we find a workforce with qualifications at an intermediate level, with specialisations in construction (going to Germany and Israel), in health (Italy, the USA, Canada and Switzerland), or hotel work and public catering (Gheţău, 2007).

Table 2. The urban-rural structure of external migrants (\%)

\begin{tabular}{|l|c|c|}
\hline \multicolumn{1}{|c|}{ Development Region } & Urban & Rural \\
\hline North-West & 51.7 & 48.3 \\
\hline Centre & 56.2 & 43.8 \\
\hline North-East & 41.9 & 58.1 \\
\hline South-East & 53.0 & 47.0 \\
\hline South-Muntenia & 39.3 & 60.7 \\
\hline Bucharest-Ilfov & 89.7 & 10.3 \\
\hline South-West Oltenia & 45.9 & 54.1 \\
\hline West & 61.4 & 38.6 \\
\hline
\end{tabular}

Source: data processed after NIS (2019). 


\section{Conclusions}

As over $3 \%$ of the world's human population now live outside their countries of birth, the effects of international migration on source countries have come to represent urgent policy questions. The social and economic consequences of out-migration are often significant, as for example when migration separates families and leaves certain members behind (Murard, 2019). In Romania, the consequences of these kinds are serious and tangible at the national, regional and local levels, and - by superimposing territorial distributions relating to the Social Disadvantage Index and the rate of out-migration - the present work produced a spatial overview in which it was possible to identify: 1) a clearly-defined area coinciding with the North-East Development Region, in which no obvious relationships exist (or at least were no longer visible by the time of the analysis): this Development Region has a low level of social development, except in the vicinity of lași and Galați where massive out-migration was reported from 2002 and 2007, respectively; and today this part of Romania no longer constitutes a pool for out-migration;

2) strong relationships in two different Development Regions i.e. South-Muntenia, and the West and Bucharest-Ilfov DRs, with the former characterised by a low level of social and serving as a pool for the out-migration of the low-skilled, while the latter are more fully-developed, but still represent an area for 'brain drain' out-migration by the more highly-qualified;

3) a large interstitial area in which relationships between social development and out-migration are quite ordinary in quantitative and structural terms, including the Centre, North-West, SouthEast and South-West Oltenia DRs (where there are low-to-medium rates of out-migration and low or medium levels of social development).

A lack of provisioning of infrastructure (in transport, and as regards hospitals and high-quality schools) applies to certain counties or rural areas and small towns, ensuring the emergence of infringements of spatial justice (as taken to denote 'the fair and equitable distribution in space of socially valued resources and opportunities to use them'; Soja, 2009, p.3). In certain Development Regions of eastern and southern Romania, the resources and possibilities mentioned by Soja (2019) do exist; but social and economic imbalance still ensures that each DR includes one or two counties 'naturally' concentrating privileges (e.g. Constanța County in the South-East Development Region, with several natural elements such as the Danube River and the Black Sea ensuring economic development), as well as others with 'historically' conditioned disadvantages ensuring the generation of spatial injustice (e.g. in communist times but persisting through to today in many southern and eastern counties of the North-East, South-East and South-West Oltenia DRs).

With the onset of the economic and financial crisis, the average level of social justice deteriorated in both OECD and EU countries. While the Social Justice Index (SJI) shows a slight but ongoing upward trend since economic recovery began in 2014, the overall score remains below the pre-crisis level. A look at the opportunities for societal participation in the Eastern European states reveals marked differences. While Slovenia (rank 7) and the Czech Republic (rank 8) are among the top ten countries, Romania (rank 39) and Bulgaria (rank 38) are at the bottom end of the ranking (Hellmann, Schmidt \& Heller, 2019). This score for SJI reinforces the relationship between the level of social development and out-migration at the national level. In line with extrapolation at the level of Development Regions, the highest values for social justice can be said to relate to low or medium values for out-migration, while lowest values relate to high values for out-migration.

The facts that $25 \%$ of employees in Romania are poor (according to Eurostat) or that the relative poverty rate remained at a relatively constant level following EU integration point to a socio-economic situation in urgent need of intervention by those making public policy. Reporting on 
the government's ability/inability to generate wellbeing among a country's citizens makes a significant contribution to decisions on migration to countries that are more developed economically an can offer higher levels of both financial and professional satisfaction than in the country of origin (Iftimoaei \& Baciu, 2018).

Romania's overall score in terms of the $\mathrm{SII}$ continues to place it among countries in most urgent need of progressive policy reforms (Hellmann et al., 2019). For imbalances induced by out-migration (e.g. on the labour market and in terms of demographic structures) to be solved, there is a need for certain action plans, programmes and strategies focused in two distinct directions, i.e. on the development of areas of origin and on special measures by which returns by emigrants can be supported. The first category encompasses many official documents adopted with a view to different geographical areas being developed (e.g. Romania's Territorial Development Strategy, the EU Strategy for the Danube Region and Regional Operational Programmes for 2014-2020) (MRDPA, 2014, 2015; EUSDR, 2015).

The second category relates to several specific action plans that include measures seeking to achieve the return of Romanian citizens working abroad. However, the impacts of these have not been assessed much, even as the few local studies that are available suggest that the effects may be zero. Beyond that, it appears that the target group is not aware of the existence of the above plans (Vlase, 2011). Central employment is a source of self-worth, self-esteem and recognition, as well as a means to overcome hardship. Conversely, it can make a person feel vulnerable when that person's expectations are no longer conformed with (Dejours, 1998).

In less-developed countries, emigration itself can be considered a strategy by which to ensure support for economic and social development. And this would also seem to be the case for Romania, given that migrants from there settling abroad tend to start sending remittances to family members back home, with these truly contributing to an enhancement of the living conditions there (Cantore \& Cali, 2015; EC, 2017), with poverty being impacted upon, and income inequality reduced. Analyses of various panel data (UN, 2011; Ciupureanu \& Roman, 2016; Peković, 2017) reveal that a $10 \%$ increase in remittances reduce the headcount as regards poverty by as much as $5.3 \%$ (or as little as $3.1 \%$ ). Moreover, remittances reduce the inequality present within given localities, as well as between urban and rural areas (Zamfir, Mocanu, Militaru \& Parciog, 2010).

\section{Acknowledgments}

The current study was carried out within the framework of a project entitled "Regional geographical studies in view of sustainable development and trans-sectoral cooperation", as part of the Research Plan of the Institute of Geography. All authors contributed equally to this paper.

\section{References}

Abreu, I., Nunes, J. M., \& Mesias, F. J. (2019). Can Rural Development Be Measured? Design and Application of a Synthetic Index to Portuguese Municipalities. Social Indicators Research, 145(3), 11071123. https://doi.org/10.1007/s11205-019-02124-w

Anania, G., \& Tenuta, A. (2006). Ruralità, urbanità e ricchezza nelle Italie contemporanee. AgriRegioni Europa, 7(2), 17-21.

Anghel, R. G., Botezat, A., Cosciug, A., Manafi, I., \& Roman, M. (2016). International migration, return migration, and their effects. A comprehensive review on the Romanian case. MPRA Paper, 75528.

Bański, J., \& Mazur, M. (2016). Classification of rural areas in Poland as an instrument of territorial policy. Land Use Policy, 54, 1-17. https://doi.org/10.1016/j.landusepol.2016.02.005 
Batsaikhan, U., Darvas, Z., \& Gonçalves Raposo, I. (2018). People on the move: migration and mobility in the European Union. Bruegel Blueprint Series, XXVIII. Retrieved from http://bruegel.org/wp-content/uploads/2018/01/People_on_the_move_ONLINE.pdf

Beine, M., Docquier, F., .\& Rapoport, H. (2001). Brain drain and economic growth: theory and evidence. Journal of Development Economics, 64(1), 275-289. https://doi.org/10.1016/S0304-3878(00)00133-4

Bhargava, A., Docquier, F., \& Moullan, Y. (2011). Modeling the effects of physician emigration on human development. Economics \& Human Biology, 9(2), 172-183.

Botezat, A., Moraru, A., \& Botezat, D. (2016). Romania's medical exodus. Evidence from Linkedln data. Working Paper. Munich Personal RePEc Archive.

Brădăţan, C., \& Kulcsár, L. J. (2014). When the Educated Leave the East: Romanian and Hungarian Skilled Immigration to the USA. Journal of International Migration and Integration, 15(3), 509-524. https:// doi.org/10.1007/s12134-013-0281-9

Cantore, N., \& Cali, M. (2015). The Impact of Temporary Migration on Source Countries. International Migration Review, 49(3), 697-726. https://doi.org/10.1111/imre.12178

Ciupureanu, C. A., \& Roman, M. D. (2016). Do remittances reduce poverty in developing countries? In A., Karasavvoglou, Z., Aranđelović, S., Marinković \& P., Polychronidou (Eds.). The First Decade of Living with the Global Crisis. Contributions to Economics (pp. 185-192). Cham, Heidelberg, New York, Dordrecht, London: Springer. https://doi.org/10.1007/978-3-319-24267-5_13

Cohen, L., \& Holliday, M. (2001). Practical Statistics for Students: An Introductory Text. London: Paul Chapman Publishing.

Copeland, P., \& Daly, M. (2012). Varieties of poverty reduction: Inserting the poverty and social exclusion target into Europe 2020. Journal of European Social Policy, 22(3), 273-287. https://doi. org/10.1177/0958928712440203

Dejours, C. (1998). Souffrance en France: la banalisation de l'injustice sociale. Paris. Éditions du Seuil.

Dijkstra, L., \& Poelman, H. (2008). Remote Rural Regions: How the proximity to a city influences the performances of rural regions. Regional Focus 1. DG Regio. Retrieved from http://ec.europa.eu/ regional_policy/sources/docgener/focus/2008_01_rural.pdf

Dijkstra, L., \& Ruiz, V. (2010). Refinement of the OECD regional typology: Economic performance of remote rural regions. DG Regio. Retrieved from http://www.oecd.org/regional/regional-policy/45511797.pdf

Docquier, F., Peri, G., \& Ruyssen, I. (2014). The cross-country determinants of potential and actual migration. International Migration Review, 48(1), 37-99. https://doi.org/10.1111/imre.12137

EC (2017). 10 trends shaping migration. Retrieved from https://ec.europa.eu/home-affairs/sites/ homeaffairs/files/10_trends_shaping_migration.pdf

EC (2018a). Country Report Romania 2018. Retrieved from https://ec.europa.eu/info/sites/info/ files/2018-european-semester-country-report-romania-en.pdf

EC (2018b). Understanding Migration in the European Union, Insights from the European Migration Network 2008-2018. Retrieved from http://extranjeros.mitramiss.gob.es/es/redeuropeamigracion/ Archivos/10_aniversario/00_10_year_anniversary_report_final_en.pdf

EIB (2016). Migration and the EU Challenges, opportunities, the role of EIB. European Investment Bank. Retrieved from https://www.eib.org/attachments/migration_and_the_eu_en.pdf

EP (2018). EU policies - Delivering for citizens. European Parliament Retrieved from http://www.europarl.europa.eu/RegData/etudes/BRIE/2019/635542/EPRS_BRI(2019)635542_EN.pdf

EUROSTAT (2019a). Eurostat Database. Retrieved from https://ec.europa.eu/eurostat/data/database

EUROSTAT (2019b). Migration and migrant population statistics. Retrieved from https://ec.europa.eu/ eurostat/statistics-explained/index.php/Migration_and_migrant_population_statistics

EUSDR (2015). EU Strategy for the Danube Region. Retrieved from http://www.danuberegion.eu/

Fererra, M. (Ed.). (2005). Welfare State Reform in Southern Europe: Fighting poverty and social exclusion in Italy, Spain, Portugal and Greece. London/New York: Routledge.

Gheţău, V. (2007). Declinul demografic şi viitorul populaţiei României. O perspectivă din anul 2007 asupra populaţiei României. INCE, Centru de cercetări Demografice "Vladimir Trebici", Academia Română. Bucharest: ALPHA MDN. 
Ghețău, V., Damian, N., \& Simion, M. (2016). Dinamică și structuri demografice. In D., Bălteanu, M., Dumitraşcu, S., Geacu, B., Mitrică \& M., Sima (Eds.). Romania. Natură și Societate (pp. 604-608). Bucharest: Romanian Academy Publishing House.

Grimm, F.-D., Friedlein, G., \& Müller, E. (1997). Central Place Systems in Central and Eastern Europe. In P., Jordan (Ed.). Atlas of Eastern and Southeastern Europe (5.3-MO1). Vienna: Oldenbourg

Hansen, T. N., lanoş, I., Pascariu, G., Platon, V., \& Sandu, D. (1996). Regional Disparities in Romania 19901994. Bucharest: Grupul de consultanţă Ramboll.

Heller, W. (2013). Who moves within the Country? Who Emigrates? Who Immigrates? Current Migrational Trends in Romania. Südosteuropa. Zeitschrift für Politik und Gesellschaft, 2, 244-267.

Hellmann, T., Schmidt, P., \& Heller, S. M. (Eds.). (2019). Social Justice in the EU and OECD. Index Report 2019. Bertesmann Stiftung. Retrieved from https://www.bertelsmann-stiftung.de/fileadmin/files/ BSt/Publikationen/GrauePublikationen/SJI_2019_In_a_nutshell_Web.pdf

Horváth, I., \& Anghel, R. G. (2009). Migration and Its Consequences for Romania. Südosteuropa. Zeitschrift für Politik und Gesellschaft, 4, 386-403.

HotNews (2015, September 4). Date statistice privind emigratia in Romania. Presedintele INS: Numarul cetatenilor care pleaca din tara este mai mare decat al celor care vin. Retrieved from http://www. hotnews.ro/stiri-esential-20399265-date-statistice-privind-emigratia-romania-presedintele-ins-numarul-cetatenilor-care-pleaca-din-tara-este-mai-mare-decat-celor-care-vin.htm

lanoş, I. (1981). Determinarea similarităţii dintre mărimile geografice. Lucrările Seminarului Geografic Dimitrie Cantemir, 1, 24-30.

Ianoș, I. (2016). Causal relationships between economic dynamics and migration: Romania as case study. In J., Domínguez-Mujica (Ed.). Global change and human mobility (pp. 303-322). Cham, Heidelberg, New York, Dordrecht, London: Springer.

Iftimoaei, C., \& Baciu, I. C. (2018). Analiza statistică a migraţiei externe după aderarea României la Uniunea Europeană. Romanian Statistical Review, Supplement 12, 166-187.

IOM (2017). World Migration Report 2018. International Organization for Migration. Retrieved from https://www.iom.int/sites/default/files/country/docs/china/r5_world_migration_report_2018_en.pdf

Marlier, E., \& Atkinson, A. B. (2010). Indicators of poverty and social exclusion in a global context. Journal of Policy Analysis and Management, 29(2), 215-420. https://doi.org/10.1002/pam.20492

Michalek, J., \& Zarnekow, N. (2012). Application of the rural development index to analysis of rural regions in Poland and Slovakia. Social Indicators Research, 105(1), 1-37. https://doi.org/10.1007/ s11205-010-9765-6

Mitrică, B., Bogardi, I., Mitrică, E., Mocanu, I., \& Minciună, M. (2017). A forecast of public water scarcity on Leu-Rotunda Plain, Romania, for the end of the $21^{\text {st }}$ century. Norsk Geografisk Tidsskrift - Norvegian Journal of Geography, 71(1), 12-29, http://dx.doi.org/10.1080/00291951.2017.1289977

MRDPA (2014). Romania's Territorial Development Strategy 2020-2035. Ministry of Regional Development and Public Administration.

MRDPA (2015). Regional Operational Programme 2014-2020. Ministry of Regional Development and Public Administration.

Murard, E. (2019). The impact of migration on family left behind: estimation in presence of intra-household selection of migrants. Discussion Paper Series, 12094. Retrieved from http://ftp.iza.org/ dp12094.pdf

NIS (2019). TEMPOONLINE - Baza de date statistice. National Institute of Statistics. Retrieved from http://statistici.insse.ro:8077/tempo-online/\#/pages/tables/insse-table

OECD (2007). OECD Regions at a Glance. Paris: OECD Publishing.

OECD (2009). Regional typology: updated statistics. Retrieved from www.oecd.org/gov/regional/statisticsindicators

OECD (2017). Romania: Country Health Profile 2017. State of Health in the EU. Brussels: OECD Publishing. http://dx.doi.org/10.1787/9789264283534-en

Peković, D. (2017). The effects of remittances on poverty alleviation in transition countries. Journal of International Studies, 10(4), 37-46. http://dx.doi:10.14254/2071-8330.2017/10-4/2 
Popescu, C., \& Săgeată, R. (2016). Regiunile de dezvoltare și politica de dezvoltare regională. In D., Bălteanu, M., Dumitraşcu, S., Geacu, B., Mitrică, \& M., Sima (Eds.). Romania. Natură și Societate (pp. 604-608). Bucharest: Romanian Academy Publishing House.

Prada, E.-M., Ciupureanu, C.-A., \& Otoiu, A. (2015). A Regional Analysis of Romanian Migration Determinants. Statistika, 95(3), 39-47.

RG/EC (1997). Carta Verde. Politica de dezvoltare regională în România. Bucharest: Romanian Government, European Commission.

Roman, M., \& Voicu, C. (2010). Some Socio-Economic Effects of Labour Migration on the Sending Country. Evidence from Romania. Economie teoretică şi aplicată, XVII, 7(548), 50-65.

Sandhu-Rojon, R. (2015). Selecting Indicators for impact evaluation. UNDP. Retrieved from https://communityindicators.net/wp-content/uploads/2018/01/Selecting-Indicators-for-Impact-Evaluation.pdf

Sandu, D. (2011). Social Disparities in the Regional Development and Policies of Romania. International Review of Social Research, 1(1), 1-30. https://doi.org/10.1515/irsr-2011-0001

Sandu, D., Radu, C., Constantinescu, M., \& Ciobanu, O. (2004). A country report on Romanian migration abroad: Stocks and flows after 1989. Prague: Multicultural Center Prague. Retrieved from http:// aa.ecn.cz/img_upload/f76c21488a048c95bc0a5f12deece153/Romanian_Migration_Abroad.pdf

Soja, E. W. (2009). The city and spatial justice. Justice spatiale, spatial justice, 1, pp. 5. Retrieved from https://www.jssj.org/wp-content/uploads/2012/12/JSSJ1-1en4.pdf

Stângă, I. C., \& Grozavu, A. (2012). Quantifying human vulnerability in rural areas: case study of Tutova Hills (Eastern Romania). Natural Hazards and Earth System Science, 12, 1987-2001. https://doi. org/10.5194/nhess-12-1987-2012

Suditu, B., Prelipcean, G., Vîrdol, D., \& Stângaciu, O. A. (2013). Perspectivele politicii de migraţie în contextul actual din România. Bucharest: Institutul European din România. Retrieved from http://www. globalization101.org/economic-effects-of-migration/

Tomescu-Dumitrescu, C. (2017). Migraţia în România şi perspectivele demografice. Analele Universităţii Constantin Brâncuşi, Serie Litere şi Ştiinţe Sociale, 79-86.

Tudor, M., \& Rusu, M. (2011). Romanian rural area typology by the inequality level - A multicriterial approach. Lucrări ştiinţifice, I(XIII), 113-120.

Tudorache, C. (2006). Evoluţia fenomenului migraţiei în Europa. Economie teoretică şi aplicată, 6, 96-100.

UN (2011). Impact of Remittances on Poverty in Developing Countries. New York, Geneva: United Nations Conference on Trade and Development. Retrieved from https://unctad.org/en/docs/ditctncd20108_en.pdf

UN (2017). International Migration Report 2017. Highlights. New York: United Nations. Retrieved from https://www.un.org/en/development/desa/population/migration/publications/migrationreport/ docs/MigrationReport2017_Highlights.pdf

van Eupen, M., Metzger, M. J., Pérez-Soba, M., Verburg, P. H., van Doorn, A., \& Bunce, R. G. H. (2012). A rural typology for strategic European policies. Land Use Policy, 29(3), 473-482. https://doi. org/10.1016/j.landusepol.2011.07.007

Victora, C. G., Black, R. E., Boerma, J. T., \& Bryce, J. (2011). Measuring impact in the Millennium Development Goal era and beyond: a new approach to large-scale effectiveness evaluations. The Lancet, 377(9759), 85-95. https://doi.org/10.1016/S0140-6736(10)60810-0

Vimont, P. (2016). Migration in Europe. Bridging the solidarity gap. Carnegie Europe. Retrieved from https://carnegieendowment.org/files/Vimont_Migration_fulltext.pdf

Vlase, I. (2011). Migraţia de întoarcere a românilor din Italia. Studiu de caz în Vulturu, Vrancea. Calitatea vieţii, XXII(2), 155-176.

World Bank (2018). Romania. Systematic country diagnostic. Background note - migration. World Bank. Retrieved from http://documents.worldbank.org/curated/en/210481530907970911/pdf/128064-SCD-PUBLIC-P160439-RomaniaSCDBackgroundNoteMigration.pdf

WEF (2017). Migration and its Impact on Cities. World Economic Forum. Retrieved from http://www3. weforum.org/docs/Migration_Impact_Cities_report_2017_low.pdf 
Zamfir, A. M., Mocanu, C., Militaru, E., \& Parciog, S. (2010). Impact of remittances on income inequalities in Romania. In U., Schuerkens (Ed.). Globalization and Transformation of Social Inequality (pp. 5875). Oxford: Taylor \& Francis Publishing House. 